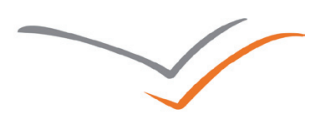

STUDIA HISTORIAE OECONOMICAE

UAM Vol. $31 \quad$ Poznań 2013

\title{
VERSITA
}

Józef Dobosz (Adam Mickiewicz University, Poznań)

\section{THE LOCATION (AND FOUNDING) OF A TOWN OF POZNAŃ IN LIGHT OF THE EARLIEST DOCUMENTS AND NARRATIVE SOURCES}

The paper addresses the issue of the origins of the town of Poznan founded in mid-13th century under German law. The birth of the charter town on the left bank of the Warta river is illustrated first and foremost by sources: documents from the mid-13th century, particularly a location charter of 1253, and narrative sources, e.g. The Wielkopolska Chronicle and yearly records written in Wielkopolska. The town was the work of Przemyst I, the duke of Wielkopolska, who sorted out property issues on the left bank of the Warta, made grants and granted privileges, erected his new castle next to the new town, and together with his brother Bolestaw issued a location charter in 1253. The duke's action resulted in the rise of one of the most important urban centers in medieval Poland.

Keywords: Poznan in the Middle Ages, town charter, $13^{\text {th }}$ century, medieval town.

doi:10.2478/sho-2013-0001

\section{INTRODUCTION}

In the Middle Ages a charter town gradually became a major element of the social and economic landscape, with time taking over the role of the centre of exchange and production from the rural environment. In itself not a product of the new civilization growing on the ruins of Imperium Romanum, yet in the emerging world, shaped by the society and barbaric states of the West and breaking the pervasive autarky and rusticity, it undoubtedly constituted a new quality. The revival of the old urban centres and the development of new ones transpired after several centuries difficulties for the rising of new political forms - the time of formation of political and territorial basis, the emergence of ruling dynasties and the establishment of a new social structure based on land economy. It was closely 
related to the changes in the technique and technology of tillage, which prompted the rural development, constant production surplus and, consequently, an increase in population. Only on this basis could a wider field be opened for exchange, trade development, and a release of the workforce in rural areas, who were aimed at new specialized production and trade centres.

The question of the emergence of towns in the area of central Europe, including the Polish lands, has for a long time been a subject of dispute in the historiography ${ }^{1}$. Noteworthy in this area is the lack of patterns of urban phenomena that occurred in the ancient world. The central issue to be addressed in the case of Poland is whether urban structures were at least partially a product of the local origin, formed from the bottom up, as a consequence of the development of local economic and social relations, or whether they are a classic import - as regards ideas, law, capital and people. While analysing the origins of Polish towns and the appearance of the so-called location threshold, it is also possible to argue for a mixed formula. For the emergence of a town in its appropriate sense, certain conditions had to be met, including the most important one - the economy based on land had to reach an appropriate level of development, with a constant surplus, so as to necessitate its becoming a centre of exchange; it also had to produce crafts inexpensively and on a relatively large scale. The mature legal, urban and social patterns developed in the West superimposed themselves onto such pre-existing conditions. The economy of the Piast state can be said to have undergone the desired changes from the second half of the 11th till the end of the 12th century. A variety of factors contributed to the improvement of the quality of land economy and the outset of surplus production, which prompted the formation of trade routes, networks of market settlements, customs houses and inns, and thus a wider circulation of money. New legal standards, commonly known as German law, were initially introduced within the rural structures (mid-12th century), and in the 13th century the process of urbanisation of the Piast lands commenced. The colonisers from the West brought

${ }^{1}$ Literature on the subject is extensive, for example, see A. Wędzki, Poczatki reformy miejskiej w środkowej Europie do połowy XIII wieku (Stowiańszczyzna Zachodnia), Warszawa 1974; B. Zientara, Przełom w rozwoju miast środkowoeuropejskich w pierwszej połowie XIII wieku, Przegląd Historyczny, 67 / 1976, pp. 219-241, and the recent comprehesive paper, providing the latest research results, see: S. Gawlas, Przełom lokacyjny w dziejach miast środkowoeuropejskich, [in:] T. Jurek, Z. Kurnatowska (Eds.), Civitas Posnaniensis. Studia z dziejów średniowiecznego Poznania, Poznań 2005, pp. 133-161, further literature therein. 
new customs, culture and capital into the areas of the Odra, Warta and Vistula rivers and grew to be a significant element of our settlement landscape, enriching the demographic potential. Having emigrated from the overpopulated West, they found their new place in the world, significantly contributing to its development ${ }^{2}$.

Carrying along a new system oflegal patterns, the colonists, in a significant partnership with the Piast rulers and the local inhabitants, made a major breakthrough in the Polish territories, namely the birth of towns based on local government, for which legal standards of German urban centres such as Magdeburg and Lübeck were employed. Attempts to define the concept have been undertaken several times - the town is perceived slightly differently by an economist (mostly in terms of its economic functions - exchange and production), an urban planner and geographer (organisation of space, territory), a sociologist (society, its organisation and structure), and finally a the legal system. All these views are important for a historian studying the emergence and dispersal of the new phenomenon in Polish territories - the town must have definite and properly organised territory (place with a specific spatial arrangement, enclosed within borders), inhabitants, accordingly grouped and engaged in wideranging non-agricultural activities, as well as a church. All these elements were present in the eleventh and twelfth centuries in Poland, as exemplified by fair settlements, often combined with customs chambers or with strongholds, sub-settlements and with small churches ${ }^{3}$. Nevertheless, the most important factor distinguishing the old exchange centres (fair settlements) from new structures (towns with local government) since the early 13 th century are legal and systemic factors. The former operated within the old monarch (common, ziemskie) law, and the latter prompted a breach of the hitherto prevailing economic order based largely on autarky and formed the foundations of a market economy. The functioning of towns was founded on the exemption from the sovereignty of the local authority

2 For more on the subject, see M. Bogucka, H. Samsonowicz, Dzieje miast i mieszczaństwa w Polsce przedrozbiorowej, Wrocław 1986, pp. 21-87, also a popular science paper by Z. Górczak, Najstarsze lokacje miejskie w Wielkopolsce (do 1314 r.), Poznań 2002 and literature from footnote 1 .

${ }^{3}$ This period of Polish economy development was once comprehensively studied by K. Buczek, Targi i miasta na prawie polskim (okres wczesnośredniowieczny), Wrocław Warszawa - Kraków 1964, passim. Cf. S. Gawlas, O ksztalt zjednoczonego królestwa. Niemieckie władztwo terytorialne a geneza społeczno-ustrojowej odrębności Polski, 2nd edition, Warszawa 2000, pp. 65ff. 
(broad immunity) and on extensive rights and liberties (local government and numerous economic freedoms) they were granted.

Therefore, the 13th century witnessed the process of the formation of urban centres based on the German law known as location (from the Latin locatio,-onis - usually translated as locating, settling, founding, but also placing) on Polish territories. This happened mostly under the patronage of the dukes of the Piast dynasty, who were interested in multiplying their income, followed by the Polish Church hierarchy, and later the nobility. The wave of location gradually covered Poland from the west: it first appeared in Silesia, and then since the 13th century systematically moved to the east, towards the Vistula ${ }^{4}$. At the peak of feudal fragmentation, more than 200 urban centres were founded under the German law. After the unification, king Casimir the Great (reigned in 1333-1370) was the strongest supporter of the phenomenon of town location. Throughout the whole 14th century, nearly 300 cities were founded, followed by another 200 by the end of the Middle Ages 5 . The location itself was not a single act, but a process frequently significantly stretched over a period of time. Perhaps its most important element was the location act (usually issued as a written document, a charter), which at the same time provided the legal warranty and set out the directions for organising an urban centre along certain rules ${ }^{6}$.

4 See M. Bogucka, H. Samsonowicz, Dzieje miast i mieszczaństwa, pp. 45ff. Earlier a monograph on the subject was written by J. Ptaśnik, Miasta i mieszczaństwo w dawnej Polsce, Kraków 1934, cf. and an attempt of a new account and summary of the state of research on the genesis and the beginnings of towns in Poland by H. Łowmiański - Poczatki Polski. Polityczne i społeczne procesy kształtowania się narodu do początku wieku XIV, vol. VI, part 2, Warszawa 1985, pp. 649-731 (here, inter alia, the following issues have been addressed: definition of a town, origins of Polish towns in the light of historiography, the question of the so-called pre-location towns, production towns); cf. papers of Sławomir Gawlas referred to in footnotes 1 and 3.

${ }^{5}$ See M. Bogucka, H. Samsonowicz, Dzieje miast i mieszczaństwa - calculations of Henryk Samsonowicz, table 3 at p. 84, see also lists of located towns according to the districts of medieval Poland at pp. 85-88.

${ }^{6}$ For more information see B. Zientara, Przemiany społeczno-gospodarcze i przestrzenne miast w dobie lokacji, [in:] A. Gieysztor, T. Rosłanowski (Eds.), Miasta doby feudalnej w Europie środkowo-wschodniej. Przemiany społeczne a układy przestrzenne, , Warszawa - Poznań - Torun 1976, pp. 67-97. 


\section{THE LOCATION OF THE CITY OF POZNAŃ}

a) First phases of the location process

Poznan was one of the towns founded by the dukes of the Piast dynasty in the 13th century ${ }^{7}$. The facts and chronology of the process of its location under German law has been a subject of discussion for years, which is primarily due to rather unclear information provided by the sources. Our knowledge of the events of mid-13th century is mostly based on documents, in various states of preservation, as well as on the enigmatic information from the Wielkopolska Chronicle (Kronika Wielkopolska), the Yearly Records of Capitularies of Poznan (Rocznik kapituty poznańskiej) and the Yearly Records of Capitularies of Gniezno (Rocznik kapituty gnieźnieńskiej). Yearly records regarding the foundation of the city are scarce and picture only the general background and circumstances of events. The first record in the Yearly Records of Capitularies of Gniezno, written down under the year 1245 , talks about the dispute between the residents of Śródka and the bishop along with the Poznan capitulary ${ }^{8}$ and indicates some property tensions at the settlement. Apparently some attempts had been undertaken to raise it to the status of an urban centre in the immediate proximity of the Poznan stronghold. Another record was written down in the Yearly Records of Capitularies of Poznan in 1249 and regards the so-called second division of Wielkopolska between Przemysł I and Bolesław the Pious, in the light of which the older brother kept for himself the strengthened or even built Poznań (literally, dux Premisl edificavit Poznań - 'duke Przemysł built Poznań'). Gniezno, along with other fortified settlements, were given to his younger brother Bolesław ${ }^{9}$. Whether this record says anything of

7 On the town location see first of all A. Rogalanka, Poznań u progu lokacji, [in:] J. Topolski (Ed.), Dzieje Poznania, , vol. I: do roku 1793, part. 1, Warszawa - Poznań 1988, pp. 146-183 and T. Jurek, Przebieg lokacji Poznania, [in:] T. Jurek, Z. Kurnatowska (Eds.), Civitas Posnaniensis. Studia z dziejów średniowiecznego Poznania, , Poznań 2005, p. 173-191 (here also T. Jasiński, Uwarunkowania lokacji Poznania, pp. 163-172).

${ }^{8}$ Rocznik kapituly gnieźnieńskiej (Yearly Records of Capitularies of Gniezno), [in:] Monumenta Poloniae Historica s.n., t. VI, published by Brygida Kürbis, Poznań 1962, p. 8 , record [42] - see the translation of the Latin text into Polish: Roczniki wielkopolskie, translated by A. Pawlaczyk in cooperation with J. Wiesiołowski, [in:] Nasi Piastowie, Poznań 1995, p. 107 (Kronika Miasta Poznania 1995, no 2).

${ }^{9}$ Rocznik kapituty poznańskiej [Yearly Records of Capitularies of Poznań], [in:] Monumenta Poloniae Historica s.n., vol. VI, published by Brygida Kürbis, Poznań 1962, p. 26 , record [27] - see: Roczniki wielkopolskie, translated by A. Pawlaczyk in cooperation with J. Wiesiołowski, 
Przemysł I's action on the left bank of the Warta or still relates to Śródka is difficult to determine. Another record in this source, published in the year 1253, clearly tells us about the foundation of the left-bank town: 'In the same year, the venerable duke Przemysł at the request of a burgher of Guben (Gubin) transferred his citizens from the city located in the area called Śródka, near the church of Saint Margaret, and moved them from that side of the Warta river near the church of Saint Martin, where another city was hitherto located, which this duke had fortified with the walls and moats $^{\prime 10}$. In this context, we can accept the hypothesis that the information of the yearly records from 1249 relates to the attempted foundation of settlement at the grounds of the settlement by St Martin's church ${ }^{11}$, which was now reinforced with settlers from Śródka. This is the insight that the yearly records provide into the origins of the city of Poznan.

The events related to the location of the town on the left bank of the Warta river are also described in the Wielkopolska Chronicle. Under the year 1249 we read therein: 'Then in Anno Domini 1249 Przemysł, the duke of Wielkopolska, rebuilt the stronghold and town of Poznan near the cathe$\mathrm{dral}^{\prime 12}$. In the context of the earlier discussed record from the yearly book we have here information on the extension of both the stronghold and the town, albeit near the cathedral. The key information from this source, put down under the year 1253 reads as follows: 'Building of the city of Poznań. At the same time, the said duke Przemysł, moved the inhabitants of Śródka [settled] near the cathedral, at the earnest request of a burgher of Guben, to the church property across the Warta river, wherein the said duke had hitherto founded the city. Soon he had it surrounded by ditches and fortified with battlements. The said Śródka he granted in perpetuity to the Poznan Church in place of the property, wherein, as we have seen, he located the city ${ }^{\prime 13}$.The information in this description is fairly general,

[in:] Nasi Piastowie, Poznań 1995, pp. 71-72 (Kronika Miasta Poznania 1995, no 2), where edificavit was translated as 'strengthened', yet, 'built' seems a better option.

10 Rocznik kapituty poznańskiej [Yearly Records of Capitularies of Poznań], [in:] Monumenta Poloniae Historica s.n., vol. VI, p. 32, record [55]; Polish translation: Roczniki wielkopolskie, p. 77.

11 Acc to. T. Jurek, Przebieg lokacji Poznania, pp. 182-184.

12 Text in Latin: Kronika Wielkopolska [Wielkopolska Chronicle], published by Brygida Kürbis, Monumenta Poloniae Historica, vol. VIII s.n., Warszawa 1970, cap. 87; Polish translation - Kronika Wielkopolska, translated by K. Abgarowicz, edited by Brygida Kürbis, Kraków 2010, chapter 87, p. 163 (1st edition Warszawa 1965).

13 Text in Latin: Kronika Wielkopolska [Wielkopolska Chronicle], cap. 100; Polish translation - Kronika Wielkopolska, translated by K. Abgarowicz, chapter 100, pp. 169-170. 
but it indicates the year of the event (although it is mentioned that the city of Poznań had allegedly been located on the left bank of the Warta river), the instigator (duke Przemysł I) and the locator (a burgher of Gubin). They emphasize the role of the inhabitants of Śródka and the issue of exchange of properties between the duke and the 'Church of Poznan', most probably the bishop. The chronicler possessed some knowledge of the founding of the city, which corresponded with the records from the yearly books, with which he was unquestionably acquainted. The difference lies only in the fact that under the year 1249 there is no information in the yearly records as regards the cathedral, while the chronicle does not mention the settlement site and St Martin's church. For a more complete picture let us compare information from narrative sources with other documented witnesses of the era.

In the year 1244 in Gniezno duke Przemysł I together with his brother Bolesław and his mother Jadwiga issued a document with no precise day given, addressed to the Dominican order of Poznań. In pursuance of this act, the monks obtained for the construction of their seat the area on the left bank of the Warta river and approved by the bishop of Poznan, Boguchwal (1242-1253), St Gothard's church and its dependencies along with the right of patronage. At the same time the bishop, with the consent of the cathedral capitulary, moved St Gothard's parish priest together with revenues due to him to the church of St Adalbert que est in monte ('which is located on the hill' - St Adalbert Hill) ${ }^{14}$. Therefore we are dealing here with the transfer of the Dominicans, recently brought into the Poznan settlement complex, from Śródka to the left bank of the Warta river, wherein they received a new home at St Gotthard's church. In addition, we find out that in this area, not far away, there was a second church, that of St Adalbert. The settlement site with St Gotthard's church was then owned by the bishopric of Poznan, while the settlement site with St Adalbert's Church was in the hands of the duke. Both temples were erected probably in the $12^{\text {th }}$ century, albeit their founder is not possible to determine - possibly Bolesław the Wry-mouthed or his immediate successor. In the events of 1244, which probably followed the settlement of relations between the heirs of Władysław Odonic and Silesian dukes, there seem to be some preliminary ducal plans for the reorganisation of the settlement and the prop-

14 The document was not translated into Polish, see Przywileje miasta Poznania XIII - XVIII wieku, published by W. Maisel, prepared for print by A. Gąsiorowski, Poznań 1994, no 1, pp. 1-2 (earlier edition: Kodeks dyplomatyczny Wielkopolski, vol. I, pulished by [I. Zakrzewski], Poznań 1877, no 243). 
erty structures on the left bank of the Warta. There is nothing in the document to suggest that Przemysł I had already commenced the location of a town here.

Another document relating to the events in question was issued by duke Przemysł I on his own, on April 24, 1252, in Gniezno. It was addressed to the Poznan church, i.e. episcopate, and it regarded first and foremost the confirmation of the privileges granted to this structure. At the same time, the duke pointed to the Poznan cathedral as his final resting place and, in exchange for handing over the land belonging to two churches - St Adalbert's and St Martin's by bishop Boguchwal, which was intended for the foundation? of the city, he gave the cathedral half of the proceeds of the Warta river and the ferry. The remaining half of the proceeds Przemysł offered to the city, and the right of the patronage of the new church built for the needs of the city's residents was to be exercised by the bishop and the capitulary. This information is consistent with the information from the Yearly Records of Capitularies of Poznan as regards settlement site by St Martin's church and with the document from 1244 regarding St Adalbert's church.

In 1244 the sons and heirs of Duke Władysław Odonic reached the settlement with the Silesian dukes and eventually took the entire Wielkopolska heritage. The elder son of Odonic, Przemysł, was able to instigate the organisation of his subject's? land. Attempts at transforming the Poznań settlement complex, most likely with Śródka intended as its economic centre, had probably been undertaken slightly later. The year 1244 is crucial inasmuch ast the dukes of Wielkopolska explicitly turned their attention to the left bank of the Warta river, albeit first they settled the Dominicans by the church of St Gothard. In subsequent years, an attempt was undertaken to locate a town under German law, having hitherto prepared the ground for the location by sorting out the property relations in the area of the settlements by the Warta river, focused around three churches: St. Gotthard's, St Adalbert's and St Martin's. This involved negotiations with Boguchwał, the bishop of Poznan, and the local cathedral capitulary, which prompted the confirmation of the existing privileges of the Poznan bishopric, exchange of lands, the erection of a new ducal abode (to become a royal castle on the Przemysł Hill) and abandonment of Ostrów Tumski. It follows that the idea of locating the city developed gradually. At first attempts were made to found a town at Śródka, and after 1244, perhaps in relation to the tensions between the inhabitants of Środka and the church, mentioned in the yearly records under the year 1245 the duke decided to un- 
dertake it on the left bank of the Warta. The sources quoted above suggest that in the spring of 1252 the process of location was already advanced the place had been chosen and at least initially prepared, property issues had been sorted out, a decision to erect a city church taken, and the settlers found. At that moment only one thing was necessary - to ensure that the new city was granted with appropriate rights and privileges in order for the whole complicated undertaking to succeed - the issue of a location charter.

b) The circumstances of issuing the location charter in 1253

Today, with the original missing, the text of the location charter of the city is known only from copies and transumpts, even though in the 18th century the document was known and submitted for approval ${ }^{15}$. It was issued in Poznan in 1253 by the dukes Przemysł I and Bolesław the Pious with the knowledge, advice and consent of the secular nobility, bishop Boguchwal and the cathedral capitulary. The dating formula does not provide the precise date ${ }^{16}$. The historiography sought to solve the puzzle of the exact date of the location act, and April 23 has been suggested (by Witold Maisel), on the basis of a eighteenth-century reference, saying that on that day in 1753, the city celebrated its five hundredth anniversa$\mathrm{ry}^{17}$. Nevertheless, the case is complicated owing to the mention of bishop Boguchwal in the document, as having provided consent for the location. We know that this prelate died on February 9, $1253^{18}$, and his successor was ordained late in the year (Piotr Prawdzic). All evidence points to

\footnotetext{
15 See Przywileje miasta Poznania XIII - XVIII wieku, no 3, pp. 4-5, wherein full information on the subject.

16 The text of the document in Latin, (in comparison to a translation into German known from a fourteenth-century copy) see Przywileje miasta Poznania XIII - XVIII wieku, no 3, pp. 5-10 (at pp. 5-6 information on issuers and consent, date p. 10), cf. Przywileje lokacyjne Krakowa i Poznania, edited by A. Kłodziński, Poznan 1947, and here the text in Latin according to a transumpt of duke Władysław the Elbow-High from 1298 reprinted from Kodeks dyplomatyczny Wielkopolski, vol. I, no 321 at pp. 24-27; also here, at pp. 27-31, translation of a document into Polish.

17 According to W. Maisel, Data przywileju lokacyjnego Poznania, [in:] Włodzimierz Błaszczyk (Ed.), Początki i rozwój Starego Miasta w Poznaniu w świetle badań archeologicznych i urbanistyczno-architektonicznych, Warszawa - Poznań 1977, pp. 111-114. A. Gąsiorowski argued against this opinion, Głos w dyskusji, [in:] Początki i rozwój, p. 138.

${ }^{18}$ On bishop Boguchwał see a short biographic note - P. Nitecki, Biskupi Kościoła w Polsce w latach 965-1999, Warszawa 2000, p. 35 (under the name of Bogufał). The date of
} 
the fact that according to the above-quoted document of 1252, the bishop granted the appropriate consent a few months before his death. At the same time, the above-quoted records mention that in Easter 1253 an agreement between Przemysł I and Bolesław the Pious was settled. The latter was freed by his brother and the inheritance left? by Odonic was divided once again (for the third time). The founding of the city was carried out afterwards ${ }^{19}$. The succession in time is unequivocal here; therefore we can accept that having imprisoned his brother in May 1250, almost three years later duke Przemysł revised his policy towards Bolesłąw and decided to buy his freedom, together with part of the heritage. The settlement was finally reached in the spring of 1253 , and there was nothing to prevent the incorporation of two dukes in the charter of the town location ${ }^{20}$. It can be assumed that the issue (announcement) of the city of Poznan location act transpired in the spring of 1253, at the earliest after Easter, on (or after?) April 20, which is not in opposition to the information on the $500^{\text {th }}$ anniversary celebration on April 23, 1753, and the position of Witold Maisel.

It seems that duke Przemysł deliberately chose the moment of founding a new urban centre by issuing a legal act. He ended the long-term dispute with his younger brother Bolesław for control over Wielkopolska and shared power with him, this time decisively. There is a possibility that Przemysł made Bolesław a co-issuer of the location charter for propaganda purposes. Yet, we have no doubt of the real initiator and organizer of the undertaking related to the establishment of a new major economic centre on the left bank of the Warta - the location of Poznan is the work of Przemysł. The very issue of the document, while not concluding the formation of the city and giving no guarantee of ultimate success, from a legal point of view created ideal conditions for that.

his death was given by Rocznik kapituty poznańskiej (Yearly Records of Capitularies of Poznań), p. 30, record [52].

${ }^{19}$ Information from Rocznik kapituty poznańskiej [Yearly Records of Capitularies of Poznań] p. 32, record [54] and [55], similarly Kronika Wielkopolska [Wielkopolska Chronicle], cap. 99 and 100 (translation Kronika Wielkopolska, pp. 169-170).

${ }^{20}$ For more on this subject, Józef Dobosz, Wokót trzeciego podziatu Wielkopolski między synów Wtadystawa Odonica, Studia Lednickie, Nr 8 / 2005, pp. 11-18. 


\section{DETERMINATION OF THE TOWN CHARTER ${ }^{21}$}

The Poznań City Charter is primarily a fairly detailed list of rights, privileges and grants supplemented by the appropriate formulas typical of medieval diplomacy. The initial fragments tell us about the issuers (dukes Przemysł and Bolesław) and their will to found a town under German law, together with the approval of bishop Boguchwal and the nobility. For this purpose, the charter was issued to a man named Thomas, who is the recipient of the document along with the townspeople ${ }^{22}$. That Thomas is commonly identified as Thomas of Guben - a locator and probably the first wójt (head of the town) of Poznañ ${ }^{23}$.

Then the issuer quickly passes to the most important issues, i.e. the rights and privileges of townspeople and wójt - this is the largest part of the document. It starts from general grants and liberties, important for the fate of the founding. The issue of a temporary exemption of inhabitants from tax obligations?, called wolnizna, is brought to the forefront. The duke appointed an eight-year period of wolnizna and added: 'In the time of wolnizna, we exempt the townspeople, arriving on our land and leaving with commodities and other goods and [passing] the river called Warta from customs duties and charges of money, and from any other taxes, with which they could be charged, except that when wolnizna is finished, they are to pay half of the duty ${ }^{24}$. The Warta river gained the status of one of the key places in the economy of the urban centre. The duke in perpetuity granted the town the river at the length of a mile (on both sides) with all benefits, first and foremost the right to fish and to erect mills. The duke reserved for himself only the right to build one mill at any place in this section of the river and in any time ${ }^{25}$.

21 See the earlier analysis of the text of the town charter by Z. Kaczmarczyk, Przywilej lokacyjny dla Poznania z r. 1253, Przegląd Zachodni, Nr 9 / 1953, no 6-8, pp. 142-166 and literature in footnotes. 5 and 15.

22 See Przywileje miasta Poznania XIII - XVIII wieku, no 3, pp. 4-5; cf. Przywileje lokacyjne Krakowa i Poznania, p. 24-25 and translation, pp. 27-28.

23 See M. Szymańska, Wójtostwo poznańskie 1253-1386, Przegląd Zachodni, Nr 9 / 1953, no 6-8, pp. 167ff, also Antoni Gąsiorowski, Zarzad miasta późnośredniowiecznego, [in:] Dzieje Poznania, vol. I, part 1, pp. 233-244.

24 Traslation: Przywileje lokacyjne Krakowa i Poznania, p. 28 and text in Latin, p. 25 (cf. Przywileje miasta Poznania XIII - XVIII wieku, nro 3, p. 5).

25 See Przywileje lokacyjne Krakowa i Poznania, p. 28 and text in Latin, p. 25 (cf. Przywileje miasta Poznania XIII - XVIII wieku, no 3, p. 5). 
In next fragment of the charter, the duke granted 17 villages to the town: Villas autem, quas sepedictam civitatem contulimus, videlicet Aratorum Campum, Poestrowo, Segram, Starolancam, Jencov, Spitcov, ambas villas, que Virbice dicuntur, Yzisz, Panczlav, Nestachow, Pentcov, Sidlov, ambas villas Vinitorum, exceptis vineis, villam Bogute, villam Unolfi $[\ldots]^{26}$. Some of the names, written down therein, sound quite familiar to the modern citizen of Poznan and today they form Poznań's constituent parts (districts, housing estates). In the Middle Ages they formed a wreath of villages surrounding the nascent city. The first village, termed in Latin Aratorum Campum stands for today's Rataje (literally 'ploughmen's fields', which the ploughman translates as rataj). In the 13th century this was a village on the right bank of the Warta. It was adjacent to Piotrowo (a village between Rataje and Chwaliszewo; its area today probably encompasses the complex of the University of Technology), Żegrze (in the Middle Ages a village south of Rataje and Piotrowo, today preserved only in the name of the street and the housing estate - Stare Żegrze) and Starołęk (a village east of Rataje, today a district of Poznań). In the next village we can see either Janikowo, or (if one record is correct - Nyencov, Nyenchow) Minikowo, today within Poznan's borders. The latter is adjacent to Starołęka, and the villages in the document are listed according to a certain order, which makes this identification plausible. Spytków, situated on the right bank of the Warta river, existed still in the 15th century and was adjacent to the above-mentioned Starołęka and Minikowo, while two villages described as Wierzbice, are the areas of the later district of Poznań, namely Wilda (Dolna and Górna Wilda). The next village is Jeżyce (in the document as Yzisz) - today the district of Poznań, and next is the unidentified Pęcław (Panczlav), probably next to Jeżyce. Identification of subsequent villages does not pose major problems - Niestachów was probably situated near Jeżyce, today within Poznańs borders (the name preserved in the form of Niestachowska Street). Piątkowo is today one of the largest districts in the northern part of Poznań, and Szydłów lay probably close (perhaps in today's disctrict

${ }^{26}$ Przywileje miasta Poznania XIII - XVIII wieku, no 3, p. 6: Villas autem, quas ad sepedicta civitatem contulimus, videlicet Aratorum Campum, poestrowo, Segram, Starolancam, Jencov, Spitcov, ambas villas, que Virbice dicuntur, Yzisz, Panczlav, Nestachow, Pentcov, Sidlov, ambas villas Vinitorum, exceptis vineis, villam Bogute, villam Unolfi, namely: 'In addition, the following villages we grant to the said town: Rataje, Piotrowo, Zegrze, Starołęka, Nyenchow, Spytków, both villages called Wierzbice, Jeżyce, Panczlaw, Niestatków, Pątków, Szydłów, both villages of wine makers except for vineyards, a village of Boguta and a village of Unolf [...]' - Polish translation: Przywileje lokacyjne Krakowa i Poznania, p. 28. 
of Naramowice?). The two villages of winnicy (wine producers; ambas villas Vinitorum) were situated in the area around the Citadel. Most probably peasants cultivating and processing grapes left their mark in the form of the names of two villages, and today the districts of Poznan - Winiary and Winogrady. The last two from the list of villages are not so easily identified - 'the village of Boguta' is undetermined, yet sometimes identified with Bogucin, and the village of Unolf is considered to have been located in the area of Umultowo ${ }^{27}$, now lying on the northern edge of the city, in the neighbourhood of Piątkowo. Nevertheless, the 'villages of Boguta and Unolf' could have been located closer to the wine makers' settlements, as identification of 'the village of Unolf' with Umultowo would violate the existing order of enumerating villages in the document.

The grant of such a large complex of villages should not be taken literally as a chartered city property, but rather a determination of its jurisdiction and the direct economic base. The duke left vineyards for himself, and in the area of listed villages he granted wójt Tomasz and his descendants (hereditary head of town) the perpetual possession of 30 lans (tany) of land for cultivation, and the townspeople a further 20 lans as pasture. More privileges apply to the profits the citizens can reap in the prescribed area. Shall the head of the town (lokator) bring German settlers to the town, once the tax-free period is finished, he will be allowed to take every fifth lan of land, provided that he pays half of grzywna of silver as tithing ${ }^{28}$. In addition, he also received the mill, formerly leased by Henryk, who was head of the settlement (soltys). All the townspeople were entitled to the present and future proceeds from mills in the mentioned villages and hunting, except for the mill owned by the Dominican order ${ }^{29}$.

The next paragraph of the document tells us about the issues of the municipal court - granting juridical immunity. Here, the act clearly indicates that the city is governed by internal law modelled on Magdeburg's, and the (German) settlers shall be tried in the first place in Poznań. Next there is a claim that no one on behalf of the duke or his representative (Castellan) participates in the courts exercised by the head of town three

27 On the identification of the villages listed in the document see Przywileje miasta Poznania XIII - XVIII wieku, no 3, p. 11 and A. Rogalanka, Poznań u progu lokacji, [in:] Dzieje Poznania, vol. I, part. 1, p.p.. 170-183. Cf. A. Gąsiorowski, Późnośredniowieczna konurbacja poznańska, [in:] Dzieje Poznania, vol. I, part 1, particularly pp. 226-229.

${ }^{28}$ Grzywna was roughly equivalent to the western mark, equal to half of a pound.

${ }^{29}$ Przywileje lokacyjne Krakowa i Poznania, p. 28 and text in Latin, p. 25 (cf. Przywileje miasta Poznania XIII - XVIII wieku, no 3, p. 6-7). 
times a year and disposes of all issues related to the city and its inhabitants. Wójt shall charge set legal fees. The burghers of Poznań, as we learn from other parts of town charter, have the right to be tried before the municipal court, headed by wójt (and his successors) holding the right to adjudicate upon disputes and all cases (arguments, beatings, etc.) between strangers and locals ${ }^{30}$.

The duke also gives the city and its citizens the privileges of an economic nature, setting the charge, once the tax free period is finished, at a half skojec ${ }^{31}$ of silver 'for each house built in the city and the gardens grown outside as well as from all the stores the citizens of that city shall be able to put up there' ${ }^{\prime 2}$. Przemysł grants the town all houses and stores within its borders and gardens beyond the borders that belonged to the town. He also exempts merchants coming to the town from customs duties and charges of money. In addition, Przemysł establishes 'In the town during the wolnizna time an annual market fair that we and our predecessors have already introduced, albeit none of the people participating in it shall be attacked' and also exempts citizens from participation in military expeditions outside the principality, from the obligation to defend. The town receives also a privilege to cut trees in the forest (in the district of the town and beyond) for the purposes of construction and the right to use their own measure unit, together with the penalty charge for the use of false units of measure. The Duke took it upon himself to provide for two crossbowmen and four guards for the protection of the town Wójt, and his successors received free 'two shops in the house, which in this town [the duke shall build] for merchants'. Besides, the townspeople were granted permission to erect a church ${ }^{33}$.

The above decisions were taken in the presence of witnesses: 'Przedpełk, wojewoda (the governor) of Poznań; Dzierżykraj, wojewoda of Gniezno; Domarat court judge; Boguchwal the Castellan of Poznan, Eustachy, son of Jan, Pakosław, son of Szczedrzyk, and many others' ${ }^{34}$, thus the nobili-

30 Przywileje lokacyjne Krakowa i Poznania, p. 29-30 and text in Latin, pp. 25-27 (cf. Przywileje miasta Poznania XIII - XVIII wieku, n0 3, pp. 7-10).

31 Skojec was equal to $1 / 24$ of grzywna.

32 Text in Polish: Przywileje lokacyjne Krakowa i Poznania, p. 29; text in Latin, ibid, p. 26 (Cf. Przywileje miasta Poznania XIII - XVIII wieku, no 3, p. 8).

33 Przywileje lokacyjne Krakowa i Poznania, pp. 29-30 (quataions from pp. 29and 30); Latin text, ibid, pp. 26-27 (Cf. Przywileje miasta Poznania XIII - XVIII wieku, no 3, pp. 8-9).

34 Przywileje lokacyjne Krakowa i Poznania, quatation from pp. 30-31; Latin text, ibid, p. 27 (cf. Przywileje miasta Poznania XIII - XVIII wieku, no 3, p. 10). In case of Boguchwał the Polish translation incorrectly says 'chancellor' instead of the Poznan 'castellan', where- 
ty occupying the highest offices at the side of both dukes of Wielkopolska: Przemysł and Bolesław.

Thirteenth-century documents and slightly later chronicle and yearly records illustrate relatively well the first years of the foundation and functioning in the Poznan settlement complex of an economic centre called the charter city. They allow for insight into the circumstances in which duke Przemysł I took the decision to establish a new urban community under German law. Notwithstanding the putative original plans to locate it at Śródka, the duke eventually chose a seat next to the settlements on the left bank of the Warta river, first and foremost the one around the church of St Martin, skilfully accommodating the interests of the duke and the Church of Poznan. His actions since the mid-1240s are planned and consistent, resulting in an effective establishment of one of the most important urban centres in medieval Poland. Whereas the documents from 1244 and 1252 demonstrate the process of sorting out the property issues within the settlement complex and laying the groundwork for the admission of new settlers, the document from 1253 (the so-called charter) gives the whole undertaking a political, legal and economical framework. While information from narrative sources sometimes slightly complements our knowledge of the early years of the city of Poznan, most of the materials at our disposal is the information from the documents. To conclude, we find out first and foremost that the duke intended to implement changes in the functioning of the place that was his political centre, that he showed determination in this area, appointed a location for a new urban centre and established frameworks for its operation. That conditions provided by Przemysł were sufficient is evident in the consolidation of his work and the development of the city in the following centuries.

Translated by Agnieszka Różańska

as in case of Pakosław, his father name is given as Cedryk instead of Szczedrzyk. On the enlisted nobility see A. Gąsiorowski (Ed.), Urzędnicy wielkopolscy XII-XV wieku. Spisy, prepared by M. Bielińska, J. Łojko, A. Gąsiorowski, Wrocław 1985, according to the alphabetic list of persons pp. 72-89. 
Józef Dobosz - Professor of history at Adam Mickiewicz University, Head of the Institute of History. He specializes in the history of the Middle Ages, especially: the beginnings of the Piast state, polish history in the era of regional divisions; history of the Polish Church in the Middle Ages, Polish-Czech relations in the Middle Ages, the beginnings of Polish diplomacy, the culture of the Middle Ages. Author and co-author of many scholar articles and numerous books. His latest book is Kazimierz II Sprawiedliwy [Casimir II the Just, 2011]. 